\title{
Positive Impact of Fish Oil on Diabetic and Hypercholestrolemic Skin Disorders
}

\begin{abstract}
The integumentary system is soft a highly organized structure of epidermis and dermis, which is tightly conjugated with each other. The epidermis represents the outer covering and is formed of epidermal layers, Langerhan, Merkel cell, melanocytes and immune cells travestied by hair follicles. Sweat glands are infiltrated throughout the integumentary layers, including fibroblast, and mast cells. Hair follicles with complex structure, characterized with their complicated structures and their internal structure contains immune cells during differentiation and possesses sebaceous glands for sebum productionthe antibacterial components. A calcium and potassium ion in close association with lipid and cholesterol represents the main elements in epidermal permeability. Keratinocytes represent the elementary part for cholesterol and lipid formation. Cholesterol overload led to altered cell structure, hair follicle formation, integrity of blood vessels and dermal collagen. It caused deformation of hair follicles and disrupted epidermal structures and keratinocyte formation leading to impairing keratinization. Fish oil represents one of the main food additives having biomedical importance. Eicosapentaenoic acid (EPA) and docosahexaenoic acid (DHA) represent their main components and play a great role in promoting permeability, growth and differentiation of the stratum corneum and inhibition of proinflammatory cytokines (tumor necrosis factor-a, interferon- $y$, and interleukin- 12 which improve the diabetic and hypercholesterolemic complications
\end{abstract}

Keywords: Skin; Diabetes; Cholesterol overload; Fish oil

\section{Abbreviations}

AGEs: Advanced Glycation End Products; BL: Basal Lamina BMP: Bone Morphogenic Protein; CDPX2: Conradi-HünermannHapple Syndrome; CHILD: Congenital Hemidysplasia with Ichthyosiform erythroderma and Limb Defects; CTS: Connective Tissue Sheath; DP: Dermal Papilla; DHC-7: Dehydrocholesterol-7; ED: Epidermal Dermal junction; EPU: Epidermal Proliferative Unit; EDA: Ectodysplasin; ER: Endoplasmic Reticulum; HFs: Hair Follicles; (HMG)-CoA: Hydromethylglutaryl Coenzyme A; HDL: High Density Lipoprotein; HC: Hair Cortex; IRS: Inner Root Sheath; IF: Intermediate Filament; K: Keratinocytes; LDL: Low-Density Lipoprotein; LEF1: Lymphoid Enhancer-Binding Factor-1; MC: Mast Cells; MMPs: Matrix Metalloproteinases; ORS: Outer Root Sheath; UVR: Ultraviolet Radiation; S-CoA: Succinyl-CoA; SC: Stratum Corneum; SGl: Sebaceous Gland; SG: Stratum Germinativum; Shh Sonic hedgehog; TRPV3: Transient Receptor Potential Channel; TA: Transit Amplifying; TGF $\beta$ s: Transforming Growth Factors $\beta$; VCAM-1: Vascular Cell Adhesion Molecule

\section{Introduction}

\section{Normal skin}

Human skin cover body surfaces and protects all body organs

\section{Journal of}

Nutrition and Health

\author{
Hassan IH El-Sayyad ${ }^{1 *}$, Mohamed E. Abdraboh ${ }^{1}$ and \\ Ahmad MA Aljebali ${ }^{2}$ \\ ${ }^{I}$ Department of Zoology, Faculty of Science, Mansoura University, \\ Egypt \\ ${ }^{2}$ Department of Zoology, Faculty of Science, Omar Al Mukhtar \\ University, Bayda, Libya \\ *Address for Correspondence \\ Hassan IH El-Sayyad, Department of Zoology, Faculty of Science, \\ Mansoura University, Mansoura, Egypt, Tel: 0020502254850; E-mail: \\ elsayyad@mans.edu.eg \\ Submission: 19 September, 2015 \\ Accepted: 24 November, 2015 \\ Published: 27 November, 2015 \\ Copyright: () 2015 El-Sayyad et al. This is an open access article \\ distributed under the Creative Commons Attribution License, which \\ permits unrestricted use, distribution, and reproduction in any medium, \\ provided the original work is properly cited.
}

against environmental stress (temperature, electrolyte/fluid balance, chemical) and microbial infection [1]. It is composed of epidermis, dermis, and subcutaneous tissue.

Epidermis: The epidermis is a non-vascularized multilayered stratified squamous epithelium, renewed throughout the life by the cornification and keratinization process. Leukocytes such as Langerhans cells and $\mathrm{T}$ cells in the epidermis and macrophage and mast cells in the dermis are the main components in mouse skin. Leukocytes are detected within or around hair follicles (HFs) which represent a reservoir of leukocyte populations in the skin [2].

The outermost Stratum corneum is a cornified layer of multilayered sheets of soft and hard keratin. The S. granulosum, a 3-5 sheets granular layer of keratinocytes producing keratohyalin granules involving in keratinization. Keratinocytes maintain epidermal homeostasis [3] as well as their cytoplasm is rich in keratohyalin filaments $(8-15 \mathrm{~nm})$ which form the cytoskeleton elements. Merkel cell and melanocytes are main elements within stratum germinativum [4]. Aged and photoaged skin exhibited a cholesterol-dominant barrier, while atopic dermatitis is associated with ceramide-dominance and a dominance of free fatty acids is associated with psoriasis [5].

The epidermal-dermal junction is a highly dynamic and complex structure that is important in the regulation of cell adhesion, differentiation, and motility; in the transmission of extracellular signals and growth factors; and in the formation of permeability barriers. It is facilitated the proliferative capacity of the epidermis. It is composed of four components including the basal cell plasma membranes with its hemidesmosomes, electron lucent lamina lucida, basal lamina and sub-basal fibrous components [6,7]. The epidermal basement membrane is also rich in proteoglycans and other proteins that act as molecular sinks for growth factors, such as TGF $\beta$ s, which restrict epidermal proliferation, and TGFa/EGFs and insulin growth factors [8].

Dermis: The dermis is located under the epidermis and is attached to it by the dermo-epidermal junction that gives skin 


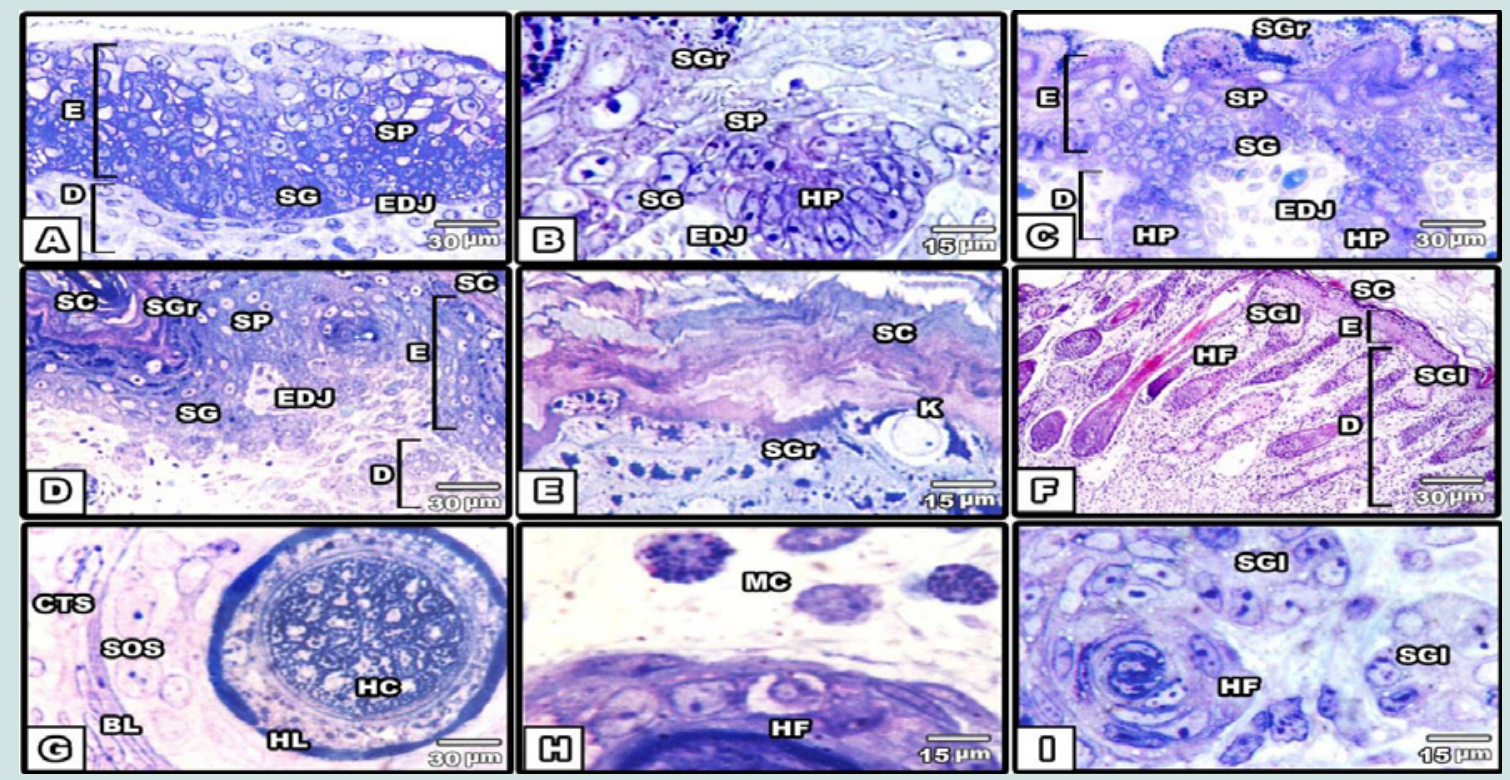

Figure 1: Photomicrographs of semi thin section of skin during prenatal development of rat. A) 13 d-old prenatal showing primitive epidermis with stratum germinativum (SG) and stratum spinosum (Sp) as well as primordium hair peg. B) and C) 15 d-old prenatal showing stages of hair follicles. Stratum granulosum (SGr) with keratohyalin granules and keratinocytes. D) 19-d-old prenatal showing development of stratum corneum (SC) and epidermal-dermal junction (EDJ). E) and F) 19-d-old prenatal showing stages of hair follicles with keratinization of inner root sheath (HF) and presence of sebaceous glands (SGI). G) 19-d-old prenatal showing stages of cross sections of hair follicles characterized by connective tissue sheath (CTS), basal lamina (BL), surface outer root sheath (SOS), Henle's layer $(\mathrm{HL})$ and keratinized inner root sheath $(\mathrm{KZ})$ and hair cortex $(\mathrm{HC}) . \mathrm{H}) 19 \mathrm{~d}$-old prenatal showing aggregation of mast cells around hair follicle. I) $19 \mathrm{~d}-\mathrm{old}$ embryo showing sebaceous gland (SGI) attached to hair follicles $[9,11]$.

enhanced mechanical stability and form niches required for activating proliferation and differentiation of keratinocyte for healing of skin appendages (Figures 1 and 2) [9].

Dermal connective tissue composed of extracellular matrix proteins such as collagen, elastic fibers, fibronectin, glycosaminoglycans, and proteoglycans [10]. Dermal papillae are present at the base of hair follicles forming a dense extracellular matrix which undergoes extensive changes in concert the hair cycle. A presumptive papilla is one of hair follicle formation and it is probable that the component cells have an inductive effects in the genesis of hair follicles in the embryo [9,11] (Figure 1).

Hair follicle: Hair follicle morphogenesis begins early in embryonic development as dermal cells populate the skin, and signals from the epithelium induce the formation of dermal papillae (DP), the mesenchymal component of the hair follicle. Epidermal invagination form the primordium of hair placode followed by differentiation and down growth forming the hair germs (Figure 1) and then hair pegs. The follicle cells are highly proliferated especially in root region. At birth, the hairs emerged the skin surface, and the sebaceous gland (SG) cells become established in the upper segment of the root (Figure 2) $[9,11]$.

The hair follicle undergoes cyclic changes and regeneration during life. Matrix cells proliferated rapidly during the growth (anagen) phase of the cycle but then suddenly undergo apoptosis. During anagen, the follicle regenerates, and required a reservoir of follicle stem cells [12] (Figure 3).

Sebaceous glands are present closely to the hair follicles forming a pilosebaceous unit. It is located in the upper portion of the hair follicle. Human sebum composed of cholesterol, cholesteryl esters, squalene, fatty acids, diglycerides and triglycerides, and wax esters [13]. The hair follicle (HF) and the sebaceous gland (SG) constitute two closely associated integral parts and contributed to biological and physiological function of mammalian skin [14].

Mast cells are important modulators of hair follicle cycling, specifically during anagen development. The distribution of mast cells in the skin varies in its distribution located mainly close to the blood vessels, smooth muscle cells, hair follicles, and nerve ending [15]. Mast cells are capable of the synthesis of a large number of pro- and anti-inflammatory mediators, including cytokines, growth factors and bioproducts of arachidonic acid metabolism[16,17]. The number of mast cells in the skin of the rat increases from the $17^{\text {th }}$ day of the embryonic period until parturition and especially around the hair follicle pulp. The dermal area is rich in blood vessels. Heparin was found to release by mast cells at normal concentration modulate growth and differentiation of matrix metalloproteinases $[18,19]$.

Lipid and cholesterol metabolism: Lipids play a main role in the maintenance of skin structure and function. Stratum corneum is composed mainly of ceramides, cholesterol, and free fatty acids which promote cell permeability [20]. Cholesterol is originated in the epidermal keratinocytes, and promotes cornification of stratum corneum in the late stages of epidermal differentiation [21].

\section{Role of Diabetes \& Hypercholesterolemia on Skin}

Diabetes mellitus is a heterogeneous group of disorders characterized by chronic hyperglycemia and deficiency in the production and secretion or action of insulin, which leads to severe complications [22]. Obesity and diabetes are considered chronic 

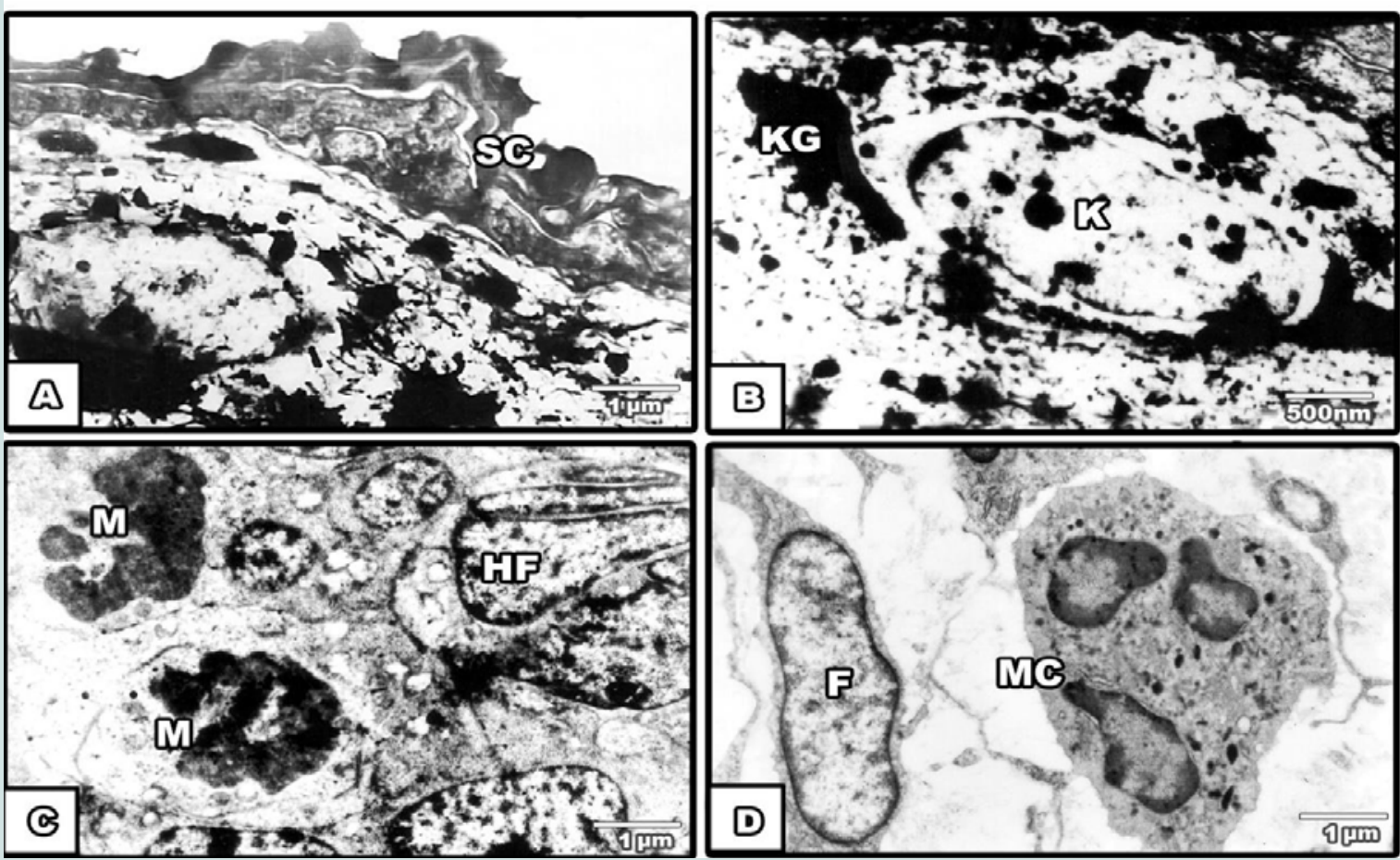

Figure 2: Transmission electron micrographs of skin of $19 \mathrm{~d}$-old rat embryo. A) and B) Epidermis showing stratum granulosum and stratum corneum. Stratum granulosum showing showing keratinocytes (K) and keratohyalin granules. C) Hair follicles (HF) with grouping macrophages (M). D) showing fibroblasts (F) and mast cell (MC) $[9,11]$.

inflammatory diseases, largely due to the inflammatory cells in white adipose tissue -including macrophages [23], B cells [24] and eosinophils [25] which promote cell-cell interaction, by releasing cell growth factors within adipose tissue. Diabetic rat showed apparent thinning of skin epidermis [26] and dermis associated with numerical reduction of mast cells [27], as well as decreased extracellular components of laminin, fibronectin and collagen [28]. There was a marked reduction of basal cell proliferation, epidermal DNA and stratum corneum turnover [29].

Perez and Kohn reported several skin disorders in diabetes mellitus such as necrobiosis lipoidica, diabetic dermopathy, diabetic bullae, yellow skin, eruptive xanthomas and perforating disorders [30]. scleredema diabeticorum is a skin complication of diabetes with deposits of collagen and aminoglycans in the dermis. Type 1 or II diabetes led to the development of scleredema in more than $50 \%$ of cases [31]. Several studies confirmed that the rates of elevated total cholesterol level and low-density lipoprotein (LDL) was reported in diabetic patients [32,33] and experimental animals [34]. Diabetic patients exhibited 2- to 6-fold increase of atherosclerosis [35] and contributed mainly to increase of cholesterol synthesis [36]. Fahien and MacDonald reported that succinate esters are potent insulin secretagogues through the generation of succinyl-CoA (S-CoA) which stimulated the formation of hydromethylglutaryl (HMG)CoA, and mevalonate-biosynthetic precursors of cholesterol [37]. Several authors have shown that cholesterol absorption is decreased and that cholesterol biosynthesis is increased in diabetes [38,39].

Following studies the skin of diabetic mice and human patients, Bermudez et al. reported down-regulated expression of genes involved in collagen synthesis in murine diabetic skin [40]. These findings may illustrate the delay of wound healing. Both diabetes $\&$ atherosclerosis may interfere with skin microcirculation [41]. By accelerating vascular permeability [42], alterations in erythrocyte velocity [43], sequestration of leukocytes in the microcirculation [44]. These alterations are mainly described as the result of hyperglycemia and increased accumulation of advanced glycation end products [45].

Beer et al. reported that diabetes increased vascular complications such as increased levels of plasma von Willebrand factor, tissue factor pathway inhibitor and the soluble form of thrombomodulin [46,47].

Although hypercholesterolemia represents a major public health problem, yet no available studies are concerned with skin disease except recently by Pietroleonardo and Ruzicka [48] who mentioned that familial hypercholesterolemia was associated with multiple types of xanthomas occur, such as tendinous, tuberous, subperiosteal, and xanthelasma as well as multiple xanthomas skin lesions in fingers, hands, elbows, knee, and feet. The matrix metalloproteinases (MMPs) are a family of zinc-binding endopeptidases capable of degrading extracellular matrix (ECM) components including collagen and proteoglycans [49]. MMPs are also involved in modulation of growth factor and cytokine function [50]. In human skin, various MMPs are expressed in several dermal diseases or in cutaneous wound healing [51,52]. MMP-9 is produced by keratinocytes, leukocytes, macrophages, and epithelial tumoral cells [53]. MMP-9 also contributes to keratinocyte hyperproliferation and progression to invasive cancer in a mouse model of oncogene-derived skin carcinogenesis [54]. 
Citation: El-Sayyad HIH, Abdraboh ME, Aljebali AMA. Positive Impact of Fish Oil on Diabetic and Hypercholestrolemic Skin Disorders. J Nutri Health. 2015;1(2): 8

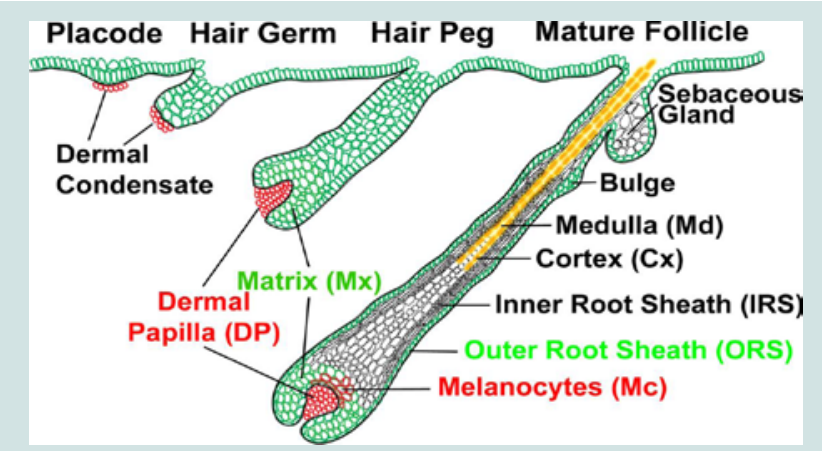

Figure 3: Diagrammatic of hair follicle morphogenesis [17]

Hypercholesterolemia exhibited a massive reduction of matrix metalloproteinases (MMPs) expression of human skin through ERK and JNK-dependent pathway [55]. Fetal skin disease of diabetic and hypercholesterolemic mother is a public health important disease as a result of widespread of both diseases with different maternal complications. The author reported that maternal diabetes or hypercholesterolemia enhanced deformations of fetal skin including retarded cornification of epidermis and differentiation of hair follicles of 15 and 19 days fetuses were following light, scanning (SEM) and transmission electron microscopy (TEM). Degeneration of stratum granulosum layer in consistent with reduction of keratinocytes was observed by reduction of cornification. Stratum germinativum and spinosum were altered and associated with massive degeneration of hair follicles. TEM illustrated deterioration of keratinocytes with apparent reduction of keratohyalin granules, the main element of stratum corneum formation as well as dramatically altered the differentiation of both stratum germinativum and spinosum cells contributed for genesis of hair follicles [56].

Ichthyosis is one of the skin disease resulted from deficiency of cholesterol in cell membranes, coupled with the accumulation of toxic sterol precursors, which impaired epidermal barrier function [57]. Cholesterol crystal embolism or atheroembolism is a disease associated with a high mortality and characterized by swelling of the venules due to obstruction of blood capillaries [58].

Mast cells (MCs) are inflammatory cells localized mainly in the dermal region where pathogens, allergens, and other environmental agents present [59].

\section{Fish-Oil and Skin Diseases}

Fish oil composed mainly of eicosapentaenoic acid (EPA; 20:5 n-3) and docosahexaenoic acid (DHA; 22:6 n-3. Omega-3 and -6 PUFAs are important components promoting cell integrity, development, maintenance, and function. Docosahexaenoic acid (DHA) showed a potent anti-inflammatory properties and high significance role in improvement of Alzheimer's disease, macular degeneration, Parkinson's disease, and other brain disorders [60]. Omega-3 fatty acids inhibited arachidonic acid synthesis and incorporation into phospholipids, decreased platelet production of thromboxane A, (TXA,), a potent vasoconstrictor and inducer of platelet aggregation, and increased production by platelets of TXA. EPA is used for synthesis of prostaglandin I, (PGI,), a potent vasodilator and inhibitor of platelet aggregation [61].
Experimental dogs received $220 \mathrm{mg} / \mathrm{kg}$ of a fish oil supplement once daily for 30 days revealed increased level of serum n-3 polyunsaturated fatty acids as well as increased circulating concentration of adiponectin in healthy non-obese dogs [62].

Dietary fish oil facilitated incorporation of PUFA (Omega-3 fatty acids) in epidermal phospholipids and the epidermal levels. Epidermal phospholipids are conjugated with eicosapentaenoic acid (EPA) and docosahexaenoic acid (DHA) forming 15-hydroxyeicosapentaenoic acid (15-HEPE) and 17-hydroxydocosahexaenoic acid (17-HDoHE). These components caused apparent inhibition of leukotriene $[63,64]$.

There were apparent depletion of type I tropocollagen, COL1A1 mRNA, hyaluronan, and hyaluronan synthase (rhas) 2 mRNA in Sprague-Dawley rats fed on high fat diet. These may interfere with dermal structure and function [65]. Oral administration of high level of omega-3 fatty acids significantly reduced the severity of dermatitis and the thickening of epidermis/dermis in a NC/Nga murine atopic model via decrease the production of interleukin (IL)-4, IL-5 and IL13 in a dose-dependent manner, as well as mRNA expression of their genes, in activated MC/9 mast cells and bone marrow-derived mast cells [66].

Fish oil administrations were also associated with improvement of atopic dermatitis, psoriasis, acne vulgaris, systemic lupus erythematosus, non-melanoma skin cancer, and melanoma. Their improvements involve promoting of the permeability, maturation and differentiation of the stratum corneum and inhibition of proinflammatory cytokines (tumor necrosis factor- $\alpha$, interferon- $\gamma$, and interleukin-12), inhibition of lipoxygenase and promotion of both wound healing, and apoptosis in melanoma cells $[67,68]$.

Dietary intake of fish oil led to marked improvement of cutaneous nerve conduction velocity in diabetic rat [69]. Diabetic mice received menhaden oil or resolvin D1 (metabolite of docosahexaenoic acid) revealed neurite outgrowth of dorsal root ganglion neurons [70] and ameliorated innervation and sensitivity of the skin of diabetic rats [71]. Dietary intake of vegetable oils, poultry, and fish and seafood was associated with improvement of microvasculature of skin of healthy subjects [72].

\section{Fish Oil and Leptin and Adiponectin}

Adipose tissue secretes a large number of hormone-like peptides called adipokines such as leptin and adiponectin [73]. Both adiponectin and leptin promote various biological functions and could play an important role in lipid and glucose metabolism [74]. Leptin, is a $16 \mathrm{kDa}$ anti-obesity hormone containing 167 amino acids, produced by adipocytes. Its receptor was expressed in epidermal cells of human and mouse skin. Topical administration of leptin significantly promoted wound healing, increased angiogenesis in dermis and activated proliferation and differentiation of epidermal keratinocytes [75]. Leptin protein expression was significantly higher in both diabetic and non-diabetic foot ulcers [76].

Adiponectin, recognized as a metabolic mediator of insulin sensitivity. Mice with adiponectin deficiency showed severe psoriasiform skin inflammation with enhanced infiltration of IL-17producing dermal $\mathrm{V} \gamma 4+\gamma \delta$-T cells [77].

Rats fed on fish oil exhibited significant increase of IL-1a and 
Citation: El-Sayyad HIH, Abdraboh ME, Aljebali AMA. Positive Impact of Fish Oil on Diabetic and Hypercholestrolemic Skin Disorders. J Nutri Health. 2015;1(2): 8

ISSN: $2469-4185$

plasma insulin [78]. Omega-3 fatty acids of marine origin exhibited strong hypolipidemic associated with a significant reduction of plasma insulin levels without changes in glucose tolerance [79].

Adiponectin is derived from adipose tissue and exhibited antiinflammatory and antiatherogenetic effects and improve insulin secretion in rodents [80] by increasing hepatic insulin activity [81]. Its plasma concentrations are depleted in obese and insulinresistant individuals, suggesting that these insulin-sensitizing effects may extend to humans [82]. Diet rich in fish oil improved the hyperlipidemic profiles and glucose homeostasis of rat fed on either a ketogenic diet [83] or fructose-rich diet [84] or sucrose rich diet [85].

Fish oil supplemented long-term rats fed on sucrose-rich diet for two improved the depletion of plasma leptin and adiponectin levels, insulin secretion, dyslipidemia, and adiposity [86]. Also, mice administered fish oil for 15 days possessed increase plasma adiponectin concentrations two- to threefold and their plasma level remain stable twofold higher for 7 days after replacement fish oil by the safflower oil diet [87]

\section{Fish Oil \& Reactive Oxygen Species}

As we know that type I diabetes is a result of destruction of the pancreatic beta cells responsible for producing insulin. In humans, $\mathrm{B}$ cell destruction is apparently mediated by white cell production of active oxygen species. By the way, induced diabetes in animals by either the drugs alloxan or streptozotocin; results in the production of active oxygen species [88]. Lipid peroxidation and lipid-derived oxidized products have been reported in hypercholesterolemia. The levels of lipid- and water-soluble antioxidants were decreased comparing with increased oxidation of lipid peroxide and LDL [89].

Both obese and obese diabetic patients exhibited apparent increase of oxidative stress manifested by elevated level of plasma MDA (end product of lipid peroxidation) with increased level of plasma dicarbonyl comparing with depletion of glutathion and super oxide dismutase [90]. Obese and non-obese patients with acne vulgaris exhibited apparent increase of serum malonadialdhyde and a decrease of $\beta$-carotene, vitamins $\mathrm{A}, \mathrm{E}$ and $\mathrm{C}$ and the activity of platelet monoamineoxidase [91]. There are several mechanisms by which obesity produces oxidative stress. One of it, the role of mitochondrial and peroxisomal oxidation of fatty acids, which involved liberation of ROS via oxidation reactions, while another is over-consumption of oxygen, which generates free radicals in the mitochondrial respiratory chain. High fat diets led to liberation of ROS through depletion of the activities of the antioxidant enzymes such as superoxide dismutase (SOD), catalase (CAT), and glutathione peroxidase (GPx) [92]. ROS such as hydrogen peroxide and superoxide are generated within the mitochondrial inner membrane, by leakage of the mitochondrial electron transport chain and rapidly react with oxygen to form free radicals [93].

Fish oil is the major source of omega-3 which composes of long-chain eicosapentaenoic (EPA) and docosahexaenoic (DHA) fatty acids. FOD significantly decreased the number of Fc receptornegative dendritic cells in cytospin-treated islets isolated from diabetic mice $[94,95]$.

Eicosapentaenoic and docosahexaenoic acid supplementation exhibited increase of the high-density lipoprotein cholesterol and depletion of low density lipoprotein in vitro [96] and prevent lipid peroxidation $[97,98]$ and increase oxidative defense glutathione reductase and glutathione peroxidase activities and blood glutathione levels in rabbits [99].

Rabbits fed a high cholesterol diet and fish oil supplementation promoted lipid peroxidation via decrease malondialdhyde and increased superoxide dismutase, which reflected a reduced free radical generation during a short-term coronary occlusion [100]. In vitro studies of endothelial cells revealed that Eicosapentaenoic acid decreased the glucose-mediated inhibition of nitrous oxide production [101]. Dietary omega-3 fatty acids increased SOD activity, NO levels and decreased TBARS [102].

Immuno staining of neonatal cutaneous sections revealed that antioxidant enzymes (catalase, SOD2, gluthatione peroxidase-1 $(\mathrm{GPx})$ ) and ROS are localized predominantly to the epidermis. Keratinocyte subpopulations showed the lowest levels of antioxidant enzymes [103].

Diabetic rats supplemented fish oil elevated arachidonic acid (omega-6) in cell membrane phospholipids resulting in a reduction in free radicals production [104].

The authors finally concluded that diabetes and or hypercholesterolemia altered skin structure and function and fish oil-supplementation scavenge the free radicals and skin structure and function of rats subjected to diabetes and or hyper cholesterolemia.

\section{References}

1. Tobin DJ (2005) Biochemistry of human skin--our brain on the outside Chem Soc Rev 35: 52-67.

2. Kumamoto T, Shalhevet D, Matsue H, Mummert ME, Ward BR, et al. (2003) Hair follicles serve as local reservoirs of skin mast cell precursors. Blood 102: $1654-1660$.

3. Blumenberg M (1993) Molecular biology of human keratin genes. In: Darmon $\mathrm{M}$, Blumenberg M, (eds). Molecular biology of the skin. The keratinocyte. San Diego: Academic Press, pp. 1-32.

4. Moll R, Divo M, Langbein L (2008) The human keratins: biology and pathology. Histochem Cell Biol 129: 705-733.

5. Chuong CM, Nickoloff BJ, Elias PM, Goldsmith LA, Macher E, et al. (2002) What is the 'true' function of skin? Exp Dermatol 11: 159-187.

6. Briggamann RA, Wheeler CE (1978) The epidermal-dermal junction. J Invest Dermatol 65: 71-84.

7. Iriyama S, Matsunaga Y, Takahashi K, Matsuzaki K, Kumagai N, et al. (2011) Activation of heparanase by ultraviolet $B$ irradiation leads to functional loss of basement membrane at the dermal-epidermal junction in human skin. Arch Dermatol Res 303: 253-261.

8. Fuchs E (2008) Skin stem cells: rising to the surface. J Cell Biol 180: 273284.

9. El-Sayyad HI (1995) Light and electron microscopic studies of hair follicle growth of virbrissae region during embryogenesis of albino rat. J Egypt Ger Soc Zool 16: 111-1142.

10. Makrantonaki E, Zouboulis CC (2007) Molecular mechanisms of skin aging: state of the art. Ann N Y Acad Sci 1119: 40-50.

11. El-Sayyad HI (1995) Light and electron microscopic studies of vibrissae skin development of albino rat. J Egypt Ger Soc Zool 16: 229-265.

12. Rendl M, Lewis L, Fuchs E (2005) Molecular dissection of mesenchymalepithelial interactions in the hair follicle. PLoS Biol 3: e331. 
Citation: El-Sayyad HIH, Abdraboh ME, Aljebali AMA. Positive Impact of Fish Oil on Diabetic and Hypercholestrolemic Skin Disorders. J Nutri Health. 2015;1(2): 8 .

ISSN: $2469-4185$

13. Smith KR, Thiboutot DM (2008) Thematic review series: Skin lipids. Sebaceous gland lipids: friend or foe? J Lipid Res 49: 271-281.

14. Frances D, Niemann C (2012) Stem cell dynamics in sebaceous gland morphogenesis in mouse skin. Develop Biol 363: 138-146.

15. Patel N, Mohammadi A, Rhatigan R (2012) A comparative analysis of mas cell quantification in five common dermatoses: lichen simplex chronicus psoriasis, Lichen planus, lupus, and insect bite/allergic contact dermatitis/ nummular dermatitis. ISRN Dermatol 2012: 5.

16. Church MK, Levi-Schaffer F (1997) The human mast cell. J Allergy Clin Immunol 99: 155-160.

17. Maurer M, Paus R, Czarnetzki BM (1995) Mast cells as modulators of hair follicle cycling. Exp Dermatol 4: 266-271.

18. Gogly B, Dridi M, Hornebeck W, Bonnefoix M, Godeau G, et al. (1999) Effect of heparin on the production of matrix metalloproteinases and tissue inhibitors of metalloproteinases by human dermal fibroblasts. Cell Biol Int 23 203-209.

19. Anower-E-Khuda MF, Habuchi $\mathrm{H}$, Nagai $\mathrm{N}$, Habuchi $\mathrm{O}$, Yokochi $\mathrm{T}$, et al. (2013) Heparan sulfate 6-O-sulfotransferase isoform-dependent regulatory effects of heparin on the activities of various proteases in mast cells and the biosynthesis of 6-O-sulfated heparin. J Biol Chem 288: 3705-3717.

20. Coderch L, Lopez O, de la Maza A, Parra JL (2003) Ceramides and skin function. Am J Clin Dermatol 4: 107-129.

21. Schmidt R, Parish EJ, Dionisius V, Cathelineau C, Michel S, et al. (1991) Modulation of cellular cholesterol and its effect on cornified envelope formation in cultured human epidermal keratinocytes. J Invest Dermatol 97: 771-775.

22. Brownlee M (2001) Biochemistry and molecular cell biology of diabetic complications. Nature 414: 813-820.

23. Xu H, Barnes GT, Yang Q, Tan G, Yang D, et al. (2003) Chronic inflammation in fat plays a crucial role in the development of obesity- related insulin resistance. J Clin Invest 112: 1821-1830.

24. Winer DA, Winer S, Shen L, Wadia PP, Yantha J, et al. (2011) B cells promote insulin resistance through modulation of $T$ cells and production of patho genic IgG antibodies. Nat Med 17: 610-617.

25. Wu D, Molofsky AB, Liang HE, Ricardo-Gonzalez RR, Jouihan HA, et al (2011) Eosinophils sustain adipose alternatively activated macrophages associated with glucose homeostasis. Science 332: 243-247.

26. Boric M, Skopljanac I, Ferhatovic L, Jelicic Kadic A, Banozic A, et al. (2013) Reduced epidermal thickness, nerve degeneration and increased painrelated behavior in rats with diabetes type 1 and 2 . J Chem Neuroanat 53 $33-40$.

27. Carvalho VF, Florim LT, de O Barreto E, Torres RC, Batista MM, et al. (2011) Inhibition of advanced glycation end products by aminoguanidine restores mast cell numbers and reactivity in alloxan-diabetic rats. Eur J Pharmacol 669: $143-148$.

28. de F Carvalho V, Campos LV, Farias-Filho FA, Florim LT, Barreto EO, et al (2008) Suppression of allergic inflammatory response in the skin of alloxandiabetic rats: relationship with reduced local mast cell numbers. Int Arch Allergy Immunol 147: 246-254

29. Sakai S, Endo Y, Ozawa N, Sugawara T, Kusaka A, et al. (2003) Characteristics of the epidermis and stratum corneum of hairless mice with experimentally induced diabetes mellitus. J Invest Dermatol 120: 79-85.

30. Perez MI, Kohn SR (1994) Cutaneous manifestations of diabetes mellitus. J Am Acad Dermatol 30: 519-531.

31. Meguerditchian C, Jacquet $P$, Béliard S, Benderitter T, Valéro R, et al. (2006) Scleredema adultorum of Buschke: an under recognized skin complicationo diabetes. Diabetes Metab 32: 481-484.

32. Abbate SL, Brunzell JD (1990) Pathophysiology of hyperlipidemia in diabetes mellitus. J Cardiovasc Pharmacol 16 Suppl 9: S1-S7.

33. Harris MI (1991) Hypercholesterolemia in diabetes and glucose intolerance in the U.S. population. Diabetes Care 14: 366-374.

34. El-Sayyad HI, Al-Haggar MS, El-Ghawet HA, Bakr IH (2012) Cardiomyopathy and angiogenesis defects of Wistar rat fetuses of diabetic and hypercholesterolemic mothers. Nutrition 28: e33- e43.

35. Haffner SM, Lehto S, Ronnemaa T, Pyorala K, Laakso M (1998) Mortality from coronary heart disease in subjects with type 2 diabetes and in nondiabetic subjects with and without prior myocardial infarction. New Engl J Med 339: 229-234.

36. Simonen PP, Gylling HK, Miettinen TA (2002) Diabetes contributes to cholesterol metabolism regardless of obesity. Diabetes Care 25: 1511-1515.

37. Fahien LA, MacDonald MJ (2002) The succinate mechanism of insulin release. Diabetes 51: 2669-2676.

38. Gylling H, Miettinen TA (1997) Cholesterol absorption, synthesis and low and high density lipoprotein metabolism in non-insulin-dependent diabetes mellitus. Diabetes Care 20: 90-95.

39. Bouissou H, de Graeve J, Legendre C, Solera ML, Wulfert E, et al. (1982) Skin cholesterol and skin apoprotein B in atherosclerosis. Biomed Pharmacother 36: 159-162.

40. Bermudez DM, Herdrich BJ, Xu J, Lind R, Beason DP, et al. (2011) Impaired biomechanical properties of diabetic skin implications in pathogenesis of diabetic wound complications. Am J Pathol 178: 2215-2223.

41. Haffner SM, Lehto S, Ronnemaa T, Pyorala K, Laakso M (1998) Mortality from coronary heart disease in subjects with type 2 diabetes and in nondiabetic subjects with and without prior myocardial infarction. $\mathrm{N}$ Engl $\mathrm{J}$ Med 339: 229-234.

42. Antonetti DA, Lieth E, Barber AJ, Gardner TW (1999) Molecular mechanisms of vascular permeability in diabetic retinopathy. Semin Ophthalmol 14: 240 248.

43. Panes J, Kurose I, Rodriguez-Vaca D, Anderson DC, Miyasaka M, et al. (1996) Diabetes exacerbates inflammatory responses to ischemiareperfusion. Circulation 93: 161-167.

44. Lutty GA, Cao J, McLeod DS (1997) Relationship of polymorphonuclear leukocytes to capillary dropout in the human diabetic choroid. Am J Patho 151: 707-714

45. Chiarelli F, Santilli F, Mohn A (2000) Role of growth factors in the development of diabetic complications. Horm Res 53: 53-67.

46. Beer S, Feihl F, Ruiz J, Juhan-Vague I, Aillaud MF, et al. (2008) Comparison of skin microvascular reactivity with hemostatic markers of endothelia dysfunction and damage in type 2 diabetes. Vasc Health Risk Manag 4 1449-1458.

47. Cheung AT, Ramanujam S, Greer DA, Kumagai LF, Aoki TT (2001) Microvascular abnormalities in the bulbar conjunctiva of patients with type 2 diabetes mellitus. Endocr Pract 7: 358-363.

48. Pietroleonardo L, Ruzicka T (2009) Skin manifestations in familial heterozygous hypercholesterolemia. Acta Dermatovenerol Alp Pannonica Adriat 18: 183-187.

49. Nagase H, Woessner JF Jr. (1999) Matrix metalloproteinases. J Biol Chem 274: 21491-21494.

50. Schonbeck U, Mach F, Libby P (1998) Generation of biologically active IL-1 beta by matrix metalloproteinases: a novel caspase-1-independent pathway of IL-1 beta processing. J Immunol 161: 3340-3346.

51. Ravanti L, Kahari VM (2000) Matrix metalloproteinases in wound repair (review). Int J Mol Med 6: 391-407.

52. Kahari VM, Saarialho-Kere U (1997) Matrix metalloproteinases in skin. Exp Dermatol 6: 199-213.

53. Rao JS, Yamamoto M, Mohaman S, Gokaslan ZL, Fuller GN, et al. (1996) Expression and localization of $92 \mathrm{kDa}$ type IV collagenase/gelatinase $\mathrm{B}$ (MMP-9) in human gliomas. Clin Exp Metastasis 14: 12-18.

54. Coussens LM, Tinkle CL, Hanahan D, Werb Z (2000) MMP-9 supplied by 
Citation: El-Sayyad HIH, Abdraboh ME, Aljebali AMA. Positive Impact of Fish Oil on Diabetic and Hypercholestrolemic Skin Disorders. J Nutri Health. 2015;1(2): 8 .

ISSN: 2469-4185

bone marrow-derived cells contributes to skin carcinogenesis. Cell 103: 481490.

55. Kim S, Kim Y, Lee Y, Cho KH, Kim KH, et al. (2007) Cholesterol inhibits MMP-9 expression in human epidermal keratinocytes and $\mathrm{HaCaT}$ cells. FEBS Lett 581: 3869-3874.

56. El-Sayyad HI, Khalifa SA, Fouda YA, Yonis AS (2012) Effects of diabetes and or hypercholesterolemia on rat foetuses skin development. Nutrition 28 : 698-706.

57. Elias PM, Williams ML, Choi EH, Feingold KR (2014) Role of cholestero sulfate in epidermal structure and function: Lessons from X-linked ichthyosis. Biochim Biophys Acta 1841: 353-361.

58. Erdim M, Tezel E, Biskin N (2006) A case of skin necrosis as a result of cholesterol crystal embolisation. J Plast Reconstr Aesthet Surg 59: 429-432.

59. Galli SJ, Kalesnikoff J, Grimbaldeston MA, Piliponsky AM, Williams CM, et al. (2005) Mast cells as "tunable" effector and immunoregulatory cells: recent advances. Annu Rev Immunol 23: 749-786.

60. Bazan NG, Molina MF, Gordon WC (2011) Docosahexaenoic acid signalolipidomics in nutrition: significance in aging, neuroinflammation, macular degeneration, Alzheimer's, and other neurodegenerative diseases. Annu Rev Nutr 31: 321-351.

61. Herolti PM, Kinsella JE (1986) Fish oil consumption and decreased risk of cardiovascular disease: a comparison of findings from animal and human feeding trials. Am J Clin Nutr 43: 566-598.

62. Mazaki-Tovi M, Abood SK, Schenck PA (2014) Fish oil supplementation increases concentration of adiponectin in healthy dogs. J Small Anim Pract 55: 247-253.

63. Miller CC, Tang W, Ziboh VA, Fletcher MP (1991) Dietary supplementation with ethyl ester concentrates of fish oil (n-3) and borage oil (n-6) polyunsaturated fatty acids induces epidermal generation of local putative anti-inflammatory metabolites. J Invest Dermatol 96: 98-103.

64. Ziboh VA, Miller CC, Cho Y (2000) Metabolism of polyunsaturated fatty acids by skin epidermal enzymes: generation of antiinflammatory and antiproliferative metabolites. Am J Clin Nutr 71: 361S-366S.

65. Yamane T, Kobayashi-Hattori K, Oishi Y, Takita T (2010) High-fat diet reduces levels of type I tropocollagen and hyaluronan in rat skin. Mol Nutr Food Res 54 Suppl 1: S53-S61.

66. Park BK, Park S, Park JB, Park MC, Min TS, et al. (2013) Omega-3 fatty acids suppress Th2-associated cytokine gene expressions and GATA transcription factors in mast cells. J Nutr Biochem 24: 868-876.

67. McCusker MM, Grant-Kels JM (2010) Healing fats of the skin: the structural and immunologic roles of the omega- 6 and omega- 3 fatty acids. Clin Dermatol 28: 440-451.

68. McDaniel JC, Massey K, Nicolaou A (2011) Fish oil supplementation alters levels of lipid mediators of inflammation in microenvironment of acute human wounds. Wound Repair Regen 19: 189-200.

69. Julu PO (1988) Essential fatty acids prevent slowed nerve conduction in streptozotocin diabetic rats. J Diabet Complications 2: 185-188.

70. Shevalye H, Yorek MS, Coppey LJ, Holmes A, Harper MM, et al. (2015) Effect of enriching the diet with menhaden oil or daily treatment with resolvin D1 on neuropathy in a mouse model of type 2 diabetes. J Neurophysiol 114 199-208.

71. Coppey LJ, Davidson EP, Obrosov A, Yorek MA (2015) Enriching the diet with menhaden oil improves peripheral neuropathy in streptozotocin-induced type 1 diabetic rats. J Neurophysiol 113: 701-708.

72. Karatzi K, Protogerou A, Kesse-Guyot E, Fezeu LK, Carette C, et al. (2014) Associations between dietary patterns and skin microcirculation in healthy subjects. Arterioscler Thromb Vasc Biol 34: 463-469.

73. Trayhurn P, Beattie JH (2001) Physiological role of adipose tissue: white adipose tissue as an endocrine and secretory organ. Proc Nutr Soc 60: 329 339.
74. Berg AH, Combs TP, Scherer PE (2002) ACRP30/adiponectin: an adipokine regulating glucose and lipid metabolism. Trends Endocrinol Metab 13: 8489 .

75. Tadokoro S, Ide S, Tokuyama R, Umeki H, Tatehara S, et al. (2015) Leptin promotes wound healing in the skin. PLoS One 10: e0121242.

76. Cao Y, Gao F, Li CZ, Xue YM (2012) Expression of leptin and its long-form receptor in the marginal cutaneous tissues of diabetic foot ulcers. Acta Diabetol 49 Suppl 1: S205-S214.

77. Shibata S, Tada Y, Hau CS, Mitsui A, Kamata M, et al. (2015) Adiponectin regulates psoriasiform skin inflammation by suppressing IL-17 production from үठ-T cells. Nat Commun 15: 7687.

78. Ling RR, Istfan N, Colon E, Bistrian BR (1993) Effect of fish oil on glucose metabolism in the interleukin-1 alpha-treated rat. Metabolism 42: 81-85.

79. Chicco A, D'Alessandro ME, Karabatas L, Gutman R, Lombardo YB (1996) Effect of moderate levels of dietary fish oil on insulin secretion and sensitivity, and pancreas insulin content in normal rats. Ann Nutr Metab 40: 61-70.

80. Combs TP, Berg AH, Obici S, Scherer PE, Rossetti L (2001) Endogenous glucose production is inhibited by the adipose-derived protein Acrp30. J Clin Invest 108: 1875-1881.

81. Scherer PE, Williams S, Fogliano M, Baldini G, Lodish HF (1995) A nove serum protein similar to $\mathrm{C} 1 \mathrm{q}$, produced exclusively in adipocytes. J Biol Chem 270: 26746-26749.

82. Tsao TS, Lodish HF, Fruebis J (2002) ACRP30, a new hormone controlling fat and glucose metabolism. Eur J Pharmacol 440: 213-221.

83. Meidenbauer JJ, Ta N, Seyfried TN (2014) Influence of a ketogenic diet fish-oil, and calorie restriction on plasma metabolites and lipids in C57BL/6 mice. Nutr Metab (Lond) 11: 23.

84. Faeh D, Minehira K, Schwarz JM, Periasamy R, Park S, et al. (2005) Effect of fructose overfeeding and fish oil administration on hepatic de novo lipogenesis and insulin sensitivity in healthy men. Diabetes 54: 1907-1913.

85. Pighin D, Karabatas L, Rossi A, Chicco A, Basabe JC, et al. (2003) Fish oil affects pancreatic fat storage, pyruvate dehydrogenase complex activity and insulin secretion in rats fed a sucrose-rich diet. J Nutr 133: 4095-4101.

86. Rossi AS, Lombardo YB, Lacorte JM, Chicco AG, Rouault C, et al. (2005) Dietary fish oil positively regulates plasma leptin and adiponectin levels in sucrose-fed, insulin-resistant rats. Am J Physiol Regul Integr Comp Physio 289: R486-R494.

87. Neschen S, Morino K, Rossbacher JC, Pongratz RL, Cline GW, et al. (2006) Fish oil regulates adiponectin secretion by a peroxisome proliferatoractivated receptor-gamma-dependent mechanism in mice. Diabetes 55 : 924-928.

88. Oberley LW (1988) Free radicals and diabetes. Free Radic Biol Med 5: 113124.

89. Moriel P, Plavnik FL, Zanella MT, Bertolami MC, Abdalla DS (2000) Lipid peroxidation and antioxidants in hyperlipidemia and hypertension. Biol Res 33: 105-112.

90. Mohora M, Vîrgolici B, Paveliu F, Lixandru D, Muscurel C, et al. (2006) Free radical activity in obese patients with type 2 diabetes mellitus. Rom $\mathrm{J}$ Intern Med 44: 69-78.

91. Abulnaja KO (2009) Oxidant/antioxidant status in obese adolescent females with acne vulgaris. Indian J Dermatol 54: 36-40.

92. Fernández-Sánchez $A$, Madrigal-Santillán E, Bautista M, Esquivel-Soto J, Morales-González A, et al. (2011) Inflammation, oxidative stress, and obesity. Int J Mol Sci 12: 3117-3132.

93. Dröge W (2002) Free radicals in the physiological control of cell function Physiol Rev 82: 47-95

94. Linn T, Noke M, Woehrle M, Kloer HU, Hammes HP, et al. (1989) Fish oilenriched diet and reduction of low-dose streptozocin-induced hyperglycemia. Inhibition of macrophage activation. Diabetes 38: 1402-1411. 
Citation: El-Sayyad HIH, Abdraboh ME, Aljebali AMA. Positive Impact of Fish Oil on Diabetic and Hypercholestrolemic Skin Disorders. J Nutri Health. 2015;1(2): 8

95. Hamadani M, Asadiagajari M, Vahdatpour T, Bahrami Y, Salehzadeh K, et al. (2011) Efficiency of dietary fish oil for regulation of hyperlipidemia and hyperglycemia in diabetic rats. Ann Biol Res 2: 75-81.

96. Foulon T, Richard MJ, Payen N, Bourrain JL, Beani JC, et al. (1999) Effects of fish oil fatty acids on plasma lipids and lipoproteins and oxidant-antioxidant imbalance in healthy subjects. Scand J Clin Lab Invest 59: 239-248.

97. Montrol VM, Farmer A, Wollan PC, Dinneen SF (2000) Fish oil supplementation in type 2 diabetes: a quantitative systematic review. Diabetes Care 23: 1407-1415.

98. Pedersen H, Petersen M, Major-Pedersen A, Jensen T, Nielsen NS, et al. (2003) Influence of fish oil supplementation on in vivo and in vitro oxidation resistance of low-density lipoprotein in type 2 diabetes. Eur J Clin Nutr 57: 713-720.

99. Iraz M, Erdogan H, Ozyurt B, Ozugurlu F, Ozgocmen S, et al. (2005) Brief communication: omega-3 essential fatty acid supplementation and erythrocyte oxidant/antioxidant status in rats. Ann Clin Lab Sci 35: 169-173.
100. Chen MF, Hsu HC, Chen WJ, Lee CM, Wu CC, et al. (1994) Fish oil supplementation attenuates free radical generation in short-term coronary occlusion-reperfusion in cholesterol-fed rabbits. Prostaglandins 47: 307 317.

101. Okuda Y, Kawashima K, Sawada T, Tsurumaru K, Asano M, et al. (1997) Eicosapentaenoic acid enhances nitric oxide production by cultured human endothelial cells. Biochem Biophys Res Commun 232: 487-491.

102. Erdogan H, Fadillioglu E, Ozgocmen S, Sogut S, Ozyurt B, et al. (2004) Effect of fish oil supplementation on plasma oxidant/antioxidant status in rats. Prostaglandins Leukot Essent Fatty Acids 71: 149-152.

103. Carr WJ, Oberley-Deegan RE, Zhang Y, Oberley CC, Oberley LW, et al. (2011) Antioxidant proteins and reactive oxygen species are decreased in a murine epidermal side population with stem cell-like characteristics. Histochem Cell Biol 135: 293-304

104. Hussein JS, EL-Khayat Z, Morsy S, Ooraby F, Singer G (2014) The effect of fish oil on oxidant/antioxidant status in diabetic rats through the reduction of arachidonic acid in the cell membrane. Int J Pharm Pharm Sci 6: 196-199. 